\title{
SHAPES OF ENERGY-ACTIVE SEGMENTS OF STEEL BUILDINGS
}

\author{
Z. KOWAL ${ }^{1}$, M. SIEDLECKA ${ }^{2}$, R. PIOTROWSKI ${ }^{3}$, \\ K. BRZEZIŃSKA ${ }^{4}$, K. OTWINOWSKA ${ }^{5}$, A. SZYCHOWSKI ${ }^{6}$
}

\begin{abstract}
The study presents the summary of the knowledge of energy-active segments of steel buildings adapted to obtain electrical energy (EE) and thermal energy (TE) from solar radiation, and to transport and store TE. The study shows a general concept of the design of energy-active segments, which are separated from conventional segments in the way that allows the equipment installation and replacement. Exemplary solutions for the design of energy-active segments, optimised with respect to the principle of minimum thermal strain and maximum structural capacity and reliability were given [34]. The following options of the building covers were considered: 1) regular structure, 2) reduced structure, 3) basket structure, 4) structure with a tie, high-pitched to allow snow sliding down the roof to enhance TE and EE obtainment. The essential task described in the study is the optimal adaptation of energy-active segments in large-volume buildings for extraction, transportation and storage of energy from solar radiation.
\end{abstract}

Keywords: energy-active cover, energy-active steel building, probabilistic optimisation, expansion segment, energy-active segment, thermal energy (TE), electrical energy (EE)

\footnotetext{
${ }^{1}$ Prof., zbigko@tu.kielce.pl; ${ }^{2}$ M. Sc., monikach@tu.kielce.pl; ${ }^{3}$ M. Sc., rafalp@tu.kielce.pl; ${ }^{4}$ M. Sc., k.brzezinska@tu.kielce.pl; ${ }^{5}$ M. Sc., karolinao@tu.kielce.pl, ${ }^{6} \mathrm{Ph} . \mathrm{D} .$, aszychow@tu.kielce.pl; Department of Mechanics, Metal Structures and Computer Methods, Faculty of Civil Engineering and Architecture, Kielce University of Technology, al. Tysiąclecia Państwa Polskiego 7, 25-314 Kielce, Poland
} 


\section{INTRODUCTION}

It is possible to adapt the design of steel buildings for active extraction, transportation and storage of thermal (TE) and electrical (EE) energy from solar radiation. The amount of energy will be sufficient to balance the costs of energy necessary to light and heat steel buildings by means of delivering summer energy surplus to the general grid.

The above concept is described in studies [1-9], patents [10-14] and patent application [15].

In recent years, the problem of energy-active structures has been discussed in the Subject: Structural solutions for energy-active building covers adapted for TE extraction. It was carried out within the frames of the Package Issues of energy efficiency and sustainable development in construction in the Project Innovative Means and Effective Methods of Improving Reliability and Service Life of Civil Engineering Structures and Transport Infrastructure in the Sustainable Development Strategy. The results of investigations were presented at national [16-26] and international [27-29] conferences, in journals [30-34] and patents [35, 36]. Presently, the investigations are carried out within the Subject Probabilistic optimisation of bar structures.

In the multi-criteria optimisation of the design of steel buildings, conventional expansion segments and energy-active segments with invariable geometry were isolated. The latter allow installation and replacement of absorbers and other equipment. It is still necessary to develop means of summer TE surplus storage. Here, the optimisation of geometric topology of the structure is relevant [34]. That is related to the analysis of kinematically admissible failure mechanisms (KAFMs) containing minimal critical set (MCS) of elements, and to the securing of the structure reliability. The basic problem of temperature impact producing increase in strain and mass of long steel buildings was solved by separating geometrically invariable energy-active segments of the building, which have the width of $\geq 4 \mathrm{a}$, in the way shown in Figs 2-4.

\section{CONCEPT OF TE EXTRACTION, TRANSPORTATION AND STORAGE}

The availability of incident solar radiation depends on the latitude and weather. Yearly irradiation of a flat surface at Poland's latitude ranges from 950 to $1250 \mathrm{kWh} / \mathrm{m}^{2}$. On average, annual sunshine hours amount to approx. 1600 hours [37], which constitutes about $18.3 \%$ in the yearly scale. Thus, Poland has good sunshine conditions, comparable with those in other European countries, like Germany (world leader in solar energy extraction), France, and Denmark [21]. 
The diagram of TE extraction, transportation and storage is shown on the example of (Fig. 1) energy-active segment of the building with a structural cover [20]. Incident solar radiation is partially absorbed by the TE absorber. On the side of incident solar radiation, the absorber is covered with a coating that facilitates TE absorption. In the convection process, the air, i.e. the working medium, contained between the glass barrier and the absorber is heated. The heat thus obtained is transported via ducts from the extraction area to the ground TE storage facility. The static scheme, in the form of pin support of the cover, adopted in the study is intended to reduce the temperature impact and to separate the global KAFMs of the cover and the columns.

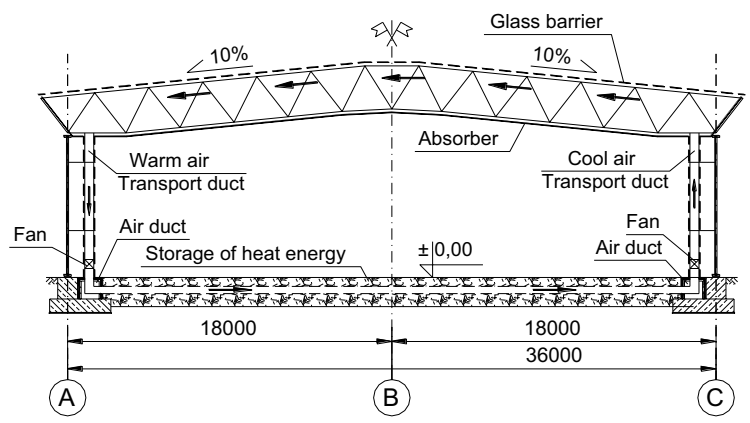

Fig. 1. Concept of the structure for extraction, transportation and storage of solar radiation TE [20]

In spring and summer, thermal energy that is extracted can be transported to, e.g. storage facility located below the building floor. The stored TE can then be used to heat the building in autumn and winter period. When the working medium is water, it is possible to use it for the structure fire protection [18].

Floor base, including stone, bricks, concrete, iron, etc. can also be used to store heat. The specific heat of those materials, however, is low and, for the same amount of heat, the required volume of the storage compartment would be twice as much as that of the water storage tank [38].

\section{SELECTED CONCEPTS OF ENERGY-ACTIVE SEGMENTS IN STEEL BUILDINGS}

South-facing walls and structural covers of industrial buildings, public buildings, sports and entertainment arenas, railway and bus stations exhibition halls, etc. are particularly well-suited for energy-active use. Measurable benefits can be also generated in buildings with girder - purlin roofs, 
truss - purlin roofs, and flat roofs used in general construction. Due to extracting TE from building roofs and side walls exposed to solar radiation, it is possible to construct complex, energy selfsufficient, and energy-active building. The analyses clearly indicate that steel buildings with structural cover are particularly well-suited for being converted into energy self-sufficient construction entities. For instance, steel buildings constructed in accordance with the "Zachód" system [40,41] are easily adaptable to TE and EE generation. The main criterion selected to assess structure adaptability to the functions of energy-active building is whether capacity and reliability of energy-active expansion segments of this building are compliant with the code [39]. Additionally, the conventional rigidity of hipped roof end is also relevant because of the necessity of protecting glass partitions against cracking. The problem of increase in the thermal strain of the building structure with an increase in geometric dimensions was solved by adopting the following principles: 1) Separation of global KAFMs of the building covers and KAFMs of columns, which was done using rigidly restrained columns and pin support of roof covers, which can be aided by spacers [24]. 2) Use of minimum 4 parallel couplings of the major structural elements in separated energy-active segments, acc. [34]. When minimum $n=4$ major decisive elements are coupled in parallel, capacity growth trend is observed [34] (3.1). The capacity takes on values that are higher than the design capacity stated in the code [39].

$$
s=\frac{\left(1-\frac{t_{2} v_{1}}{\sqrt{n}}\right)}{1-t_{2} v_{1}}
$$

where: $t_{2}$ - reliability index acc. [39]; $v_{1}$ - variation coefficient; $n$ - number of coupled elements.

For the case when capacity variation coefficient $v_{1}=0.06$, increase in the capacity of coupled elements of Class RC2 structure, having the reliability index $t_{2}=3.8$ [39], amounts to:

$$
s=\frac{\left(1-\frac{3,8 \cdot 0,06}{\sqrt{4}}\right)}{1-3,8 \cdot 0,06}=\frac{0,886}{0,772}=1,148
$$

When the number elements that are coupled is greater, $n>4$, their reliability and capacity increase as shown in Table 1 in study [34].

Variation coefficient of the element capacity [34], acc. formula (3.2):

$$
v=\frac{D(Z)}{E(N)}
$$

is the quality coefficient of the workmanship of the structural components, where $D(Z)$ - capacity standard deviation, $\mathrm{E}(\mathrm{N})$ - capacity expected (mean) value. The examples of energy-active 
structures, shown in the present study, satisfy the condition of the parallel coupling of the decisive elements of the structure.

3) In energy-active segments of the buildings, it is necessary to account for considerable temperature impact on the structure strain, the necessity of TE transportation, and automatic ventilation that needs to switch on when the structure is exposed to excessive TE, especially in summer period.

Thermal hazard can be significantly limited on the basis of energy balance (in which TE storage facilities are included, located, e.g. under energy-active segments), when the following are taken into account:

1. the building structure division into conventional expansion segments and energy-active segments;

2. expansion segments division into assemblies.

In the building division into energy-active and passive expansion segments, the following should be considered:

- efficient management of the extracted thermal energy, starting from the situation of energy deficit in winter to energy surplus in summer,

- separation of TE absorbers from the load-bearing structure of energy-active segments,

- snow and dust removal from energy-active segment to increase their irradiation.

Expansion segments with regular and reduced spatial structure, e.g. those in accordance with the "Zachód" system [16,18,19], can be adapted to perform energy-active functions.

Figure 2 shows a reduced structure (with a tie) with a high slope [25-26]. In Fig. 3, segment of the basket structure is presented, acc. [23,29].

The basic criterion in the building division, in a conservative manner, into self-supporting energyactive and conventional expansion segments is preserving the recommended [39] capacity and reliability of separated energy-active segments [17,23,25,26,29,32,33,34]. The trend towards limiting the dimensions of the energy-active segments is driven by the necessity of lowering the additional thermal strain of the elements in KAFM. A reduction in the width, measured by a number of meshes (n-a) in energy-active segments contributes to a decrease in the thermal load on those. Keeping the width of energy-active segment at $4 \mathrm{a}$ allows parallel coupling of elements in the KAFM and maintaining capacity and reliability of energy-active segments of the building, which were dimensioned in accordance with the code in force [39]. 


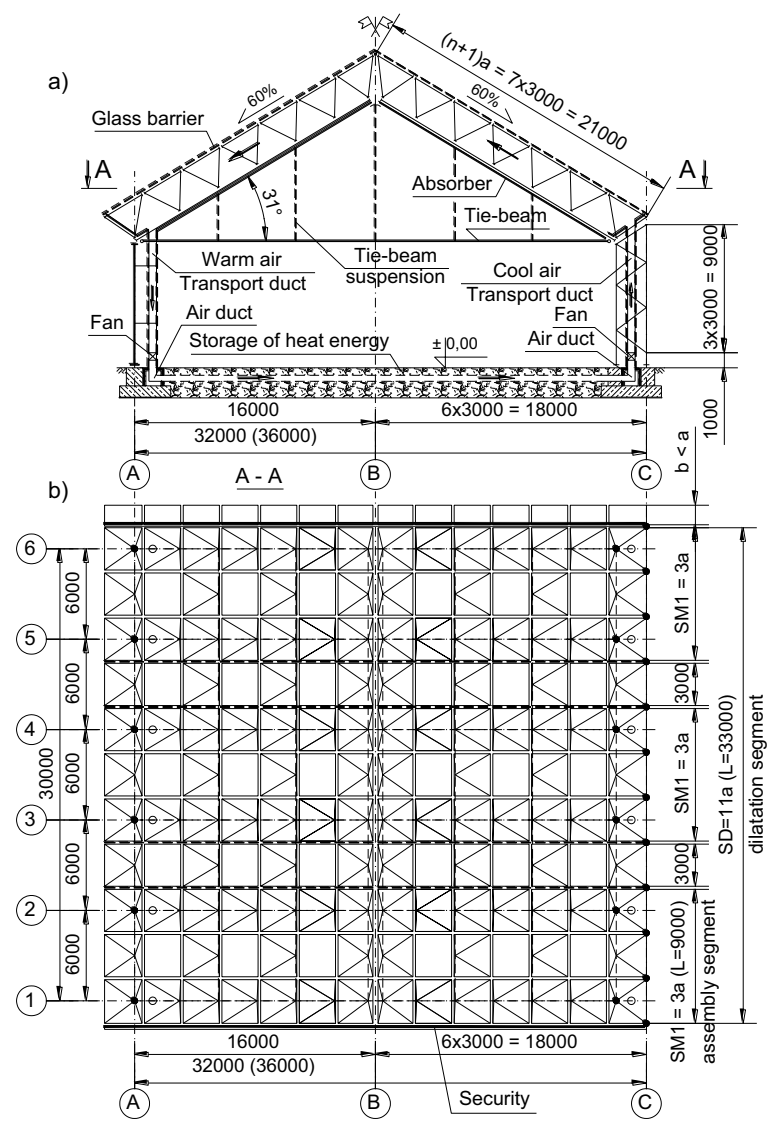

Fig. 2. Energy-active segment of the structure with a tie: a) section, b) expansion segment division into assemblies [25]

It is also important to apply the concept, used in studies [20,22,23,25,26,29], which concerns the structure division into shipped elements that are joined into geometrically invariable structure segments at the building site. Assemblies are directly mounted on column heads and bolted together to form energy-active, geometrically invariable expansion segments that show reduced sensitivity to thermal effects. As regards structural roof covers, energy-active expansion segments can be wholly assembled at the ground level, and then mounted on the columns.

Taking into account all the assumptions above, the preferred length of energy-active expansion segments was selected. For buildings covered with regular structures, the width of the minimal assembly is $\mathbf{2}$ meshes $(2 \mathrm{a}=\mathbf{6 m})$, which gives the length of the minimal energy-active expansion 
segment $L d=3 \times 2 a=6 a=18 m$ (Fig. $3 b$ ). For buildings covered with reduced structures, the width of the minimal assembly is 3 meshes $(3 \mathrm{a}=9 \mathrm{~m})$, which gives the length of the minimal energy-active expansion segment $L d=3 \times 3 a+2 a=11 a=33 m$.

The major advantage of using regular bar structures in energy-active building segments that have a sufficient number of meshes calculated along the building is the fact that the capacity and reliability of separated building segments are higher than those recommended in the code [39]. That refers to the segments that have the width of minimum 4 meshes (4a) for regular structures. For the structures with every other mesh empty, the minimum width is 7 meshes (7a).
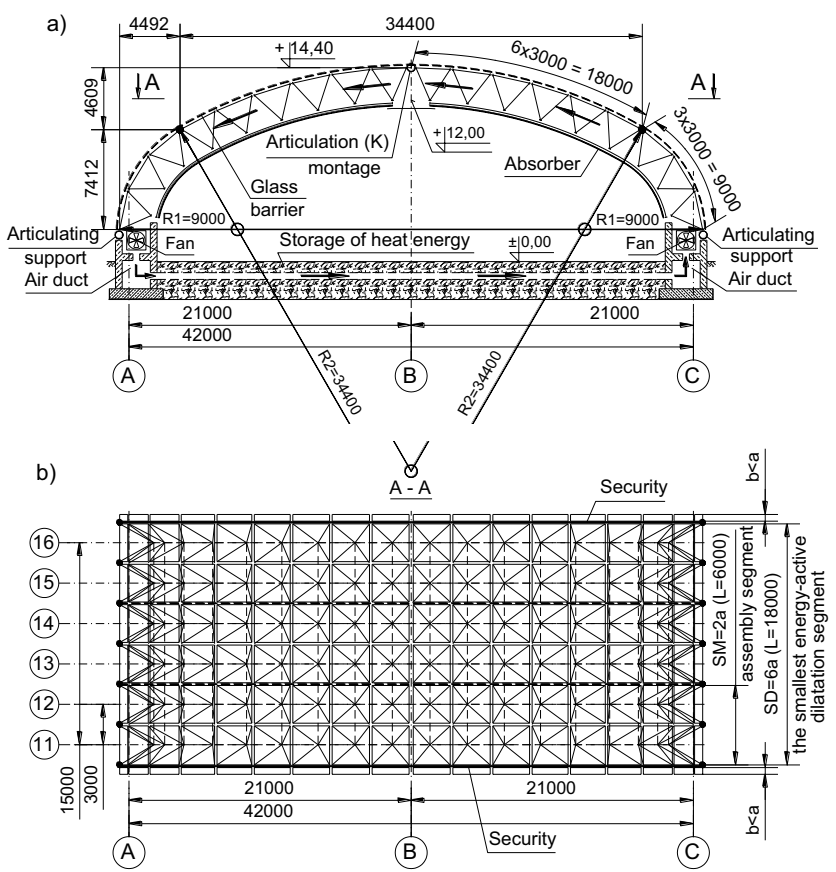

Fig. 3. Energy-active basket structure: a) section, b) expansion segment division into assemblies [23]

The length of the privileged expansion segments is limited by the distribution of expansion joints. In the structures under consideration, it was assumed that the length is $\mathrm{L}=10 \mathrm{a}=30 \mathrm{~m}$. The privileged number of meshes in energy-active segments isolated along the building was determined using optimisation probabilistic instruments [20,22,23,25,26,29], generalised in studies [17,32,34]. It should be noted that thermal strain of the minimal energy-active segment with every other empty mesh is higher than thermal strain in regular energy-active segments. 
A connection, in the form of an empty mesh, having a width of $\mathrm{b}<\mathrm{a}$, was used between expansion segments. It produced a relief for the outermost top and bottom chords (Fig. 2b, 3b) and provided protection against non-symmetric displacement of the virtual nodes of kinematically admissible failure mechanisms (KAFMs).

The arrangement of [23] energy-active expansion segments is shown with hatched areas in Fig. 4.
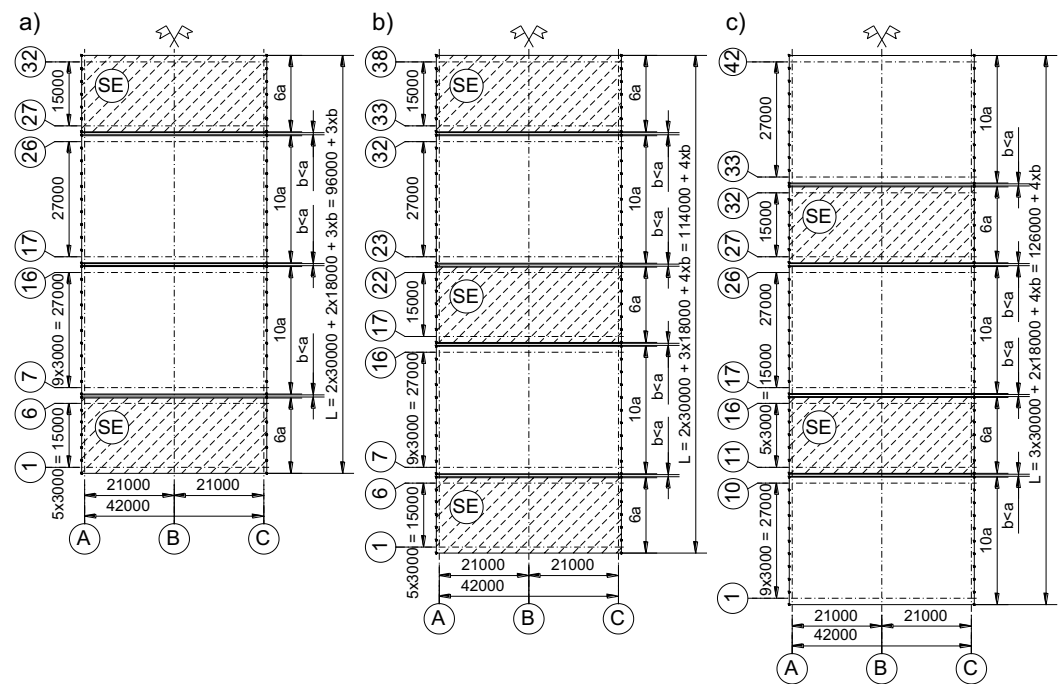

Fig. 4. Examples of the arrangement of energy-active (SE) segments of the building [23] - hatched areas

\section{SUMMARY}

The solutions presented in the study take into account the occurrence of short-term (day and night), long-term (seasonal surplus and deficit of solar TE) changes in solar TE supply, and additionally a decrease in TE supply due to snowfall and pollution. The application of self-clearing covers (Fig. 2) with the pitch above $10^{0}$ and of hydrophilic coatings, acc. study [22], giving reduced snow load was presented in the study. It was also shown how the cover clearing of snow can be facilitated by heating, e.g. with warm air, the cross connection for water downflow.

Because of the possibility that TE absorbers will be heated to a few hundred degrees, the option of solar TE automatic transportation at the instant the air temperature exceeds a certain value, e.g. $25^{\circ} \mathrm{C}$, and that of automatic (emergency) switching on of ventilation are included. 
The analysis of thermal effects produced by heated absorbers indicated the necessity of separating TE absorbers from the bearing structure elements. From the economic and technical standpoint, an essential issue is a reduction in the thermal strain of the energy-active structure. Taking into account the effect of excessive temperature on the strain of conventional building structure leads to substantial increase in displacements of the structure nodes, in the strain of the statically indeterminate structure elements, and in the mass of the structure. Also, damages to the casing, partitions and structure elements can occur. The isolation, i.e. separation, of the energy-active segments of the structure proved the most advantageous solution. That was done using probabilistic optimisation of the structure capacity and reliability.

Truss - purlin traditional buildings show lower capacity and reliability than those recommended by the code [39]. The reasons for that were presented in studies [17,32]. The major disadvantage of truss - purlin solutions in traditional buildings concerns their decreasing capacity and reliability with a growing number of KAFMs that have a small number of decisive elements in associated MCSs.

Studies $[16,18]$ demonstrate that for the adaptation of traditional steel buildings so that they could have energy-active functions, it is obligatory to introduce the following: 1) continuous longitudinal roof bracings, which couple column heads in energy-active segments, 2) continuous transverse bracings between trusses, which transfer differences in transverse forces. Elements that couple vertical truss displacements, in addition to the transfer of transverse forces $[16,18]$, have to facilitate the support, with separation, of the devices (and equipment), especially those directly heated due to exposure to solar radiation.

Structural covers with every other empty mesh have sufficient rigidity of hipped roof end for the coupling of the displacements of column heads and transverse stiffness for the coupling of the vertical structure displacements. A major advantage of structural covers lies in the fact that stiffnesses resulting from geometric topology can be used to couple elements in the KAFM of separated energy-active segments.

The use of ties and hinge in the roof ridge in structural, high-pitched covers leads to an increase in the number of KAFMs of the cover, and thus to reduced reliability. In this case, the idea of mechanical securing was proposed to maintain capacity and reliability by restraining the movement in the pin connections in the roof ridge, which couple the left and right slopes of high-pitched roofs. Alternative solutions for steel building design, aimed at reducing temperature impact on the structure strain, were analysed. Those involved three-pin, basket arch structures with regular meshes and every other mesh empty. In such structural covers of steel buildings, mechanical 
restraint of rotational displacements in the pins can also be used. That depends on the range of thermal effects, and in the extreme cases, no pinned connections are used. A clear advantage offered by energy-active basket arch segments constructed from regular structures concerns the fact that when dimensioned in accordance with the code, their capacity and reliability are higher than recommended [39]. That was demonstrated by the analysis performed with quantile algebra.

Generally, the advantage of using bar structures, calculated on the basis of the code [42], in w energy-active segments of steel buildings, with sufficient number of meshes calculated along the building, is the fact that the capacity and reliability of isolated building segments are higher than code recommendations [39]. That refers to segments having the width of minimum 4 meshes for regular structures, whereas for structures with every other mesh empty, the width is minimum 7 meshes. 


\section{REFERENCES}

1 Kowal Z., Szychowski A.: Energy-active arch structures as roof covers (in Polish), $38 \mathrm{KN}$ KILiW PAN i KN PZITB, Krynica 1992, pp. 47-52.

2 Kowal Z., Szychowski A.: Structures spatiales energoactives, Int. Seminar on Structural Morphology, Montpellier 7-11.09.1992, France, pp. 370-378.

3 Kowal Z., Szychowski A.: Energy-active spatial structures (in Polish), Inż. i Bud. 1/1993, pp. 3-5.

4 Kowal Z., Malec M.: Steel energy-active girders as elements of load-carrying structures, Harmony with Nature, Ises Solar World Congress, Budapest 1993, pp.756-756.

5 Kowal Z, Szychowski A.: Solar structures in the construction of halls, Solar World Congress, Budapest 1993.

6 Kowal Z., Szychowski A.: Energy-active arch covers (in Polish), Inż. i Bud. 6/1994.

7 Kowal Z., Szychowski A.: Solar structures in steel building construction (in Polish), Inż. i Bud. 9/1995, pp. 491 493.

8 Kowal Z., Malec M.: Triple-chord energy-active girders with water transportation (in Polish), Conference materials „Budownictwo Ekologiczne”. Wydawnictwo Politechniki Częstochowskiej, Częstochowa 1995, pp.21-27.

9 Kowal Z., Mirski J.Z.: Two-layer bar domes in the construction of warehouses and solar drying plants (in Polish), Konferencja Naukowo-Techniczna „Budownictwo ogólne”, Bydgoszcz, 12.06.2000, pp.73-80.

10 Kowal Z., Szychowski A., Patent No. 166877 Spatial building structure for thermal energy extraction (in Polish), UP RP Warszawa 1995.

11 Kowal Z., Szychowski A., Patent No. 168709 Building arch covers for thermal energy extraction (in Polish). UP RP Warszawa 1996.

12 Kowal Z., Szychowski A., Patent No. 182933 Truss-purlin roof for thermal energy extraction (in Polish). UP RP Warszawa 2002.

13 Kowal Z., Mirski J.Z., Patent P-339957, Two-layer bar dome covers for thermal energy extraction, UP RP Warszawa 2007.

14 Szychowski A., Patent No. 202436 Flat roof for thermal energy extraction (in Polish), UP RP Warszawa 2009.

15 Siedlecka M., Szychowski A.: Design of steel building cover from solid steel elements for thermal energy extraction (in Polish), Patent application PL405341A1 of 16.09.2013, BUP 20/2014, pp. 31-32.

16 Kowal Z., Piotrowski R., Szychowski A.: Rigidity of hipped roof end bar structures with square meshes (in Polish), Zeszyty Naukowe Politechniki Rzeszowskiej Nr 276, Seria: Budownictwo i Inżynieria Środowiska, Zeszyt 58,Nr 3/2011/II, pp. 249-256.

17 Kowal Z.: Probabilistic optimisation of the capacity of steel columns of conventional steel buildings (in Polish), Zeszyty Naukowe Politechniki Rzeszowskiej Nr 283, Seria: Budownictwo i Inżynieria Środowiska, Zeszyt 59, Nr 3/2012/II, pp. 185-192.

18 Kowal Z., Otwinowska K., Szychowski A.: Rigidity of hipped roof end truss-purlin steel buildings adapted for thermal energy extraction from solar radiation (in Polish), Zeszyty Naukowe Politechniki Rzeszowskiej Nr 283, Seria: Budownictwo i Inżynieria Środowiska, Zeszyt 59, Nr 3/2012/II, pp. 193-200.

19 Kowal Z., Piotrowski R., Szychowski A.: Adaptation of steel buildings covered with a structure adapted for thermal energy extraction from solar radiation (in Polish), Zeszyty Naukowe Politechniki Rzeszowskiej Nr 283, Seria: Budownictwo i Inżynieria Środowiska, Zeszyt 59, Nr 2/2012/II, pp. 431-438.

20 Kowal Z., Piotrowski R.: Energy-active expansion segments of steel buildings with structural cover (in Polish), Budownictwo i Architektura, 2013, 12 (2), pp. 121-128.

21 Otwinowska K., Piotrowski R.: Adaptation of selected steel buildings for thermal energy absorption from solar radiation (in Polish) in: Wybrane problemy naukowo-badawcze budownictwa i inżynierii środowiska, dr. inż. Andrzej Dzięgielewski (editor), Część IV Analiza energetyczna obiektów budowlanych oraz pozyskiwanie energii ze źródeł odnawialnych, 2013, pp. 281-292

22 Kowal Z., Siedlecka M.: Energy-active segments of self-clearing cover of steel buildings (in Polish), Conference materials XXI Interdyscyplinarna Ogólnopolska Konferencja Naukowo-Techniczna "Ekologia a Budownictwo", Bielsko-Biała, 10-12 Oct 2013, pp. 161-168.

23 Kowal Z., Piotrowski R.: Energy-active segments of steel buildings covered with a regular basket structure (in Polish), Journal of Civil Engineering, Environment and Architecture, t. XXXII, z. 62 (2/15), April-June 2015, pp. 189-196.

24 Brzezińska K., Kowal Z.: Temperature impact on kinematically admissible failure mechanisms of energy-active segments of steel buildings (in Polish), Konferencja Naukowo-Techniczna - Konstrukcje Metalowe ZK2014, Kielce-Suchedniów 2014, pp. 19-22. 
25 Kowal Z., Piotrowski R., Siedlecka M.: Secured energy-active segment of the steel building, covered with reduced structure with a tie (in Polish), Konferencja Naukowo-Techniczna - Konstrukcje Metalowe ZK2014, KielceSuchedniów 2014, pp. 36-39.

26 Kowal Z., Piotrowski R.: Energy-active expansion segments covered with regular structure with a tie (in Polish), paper accepted for $60 \mathrm{KN}$ KILiW PAN i KN PZITB, Krynica 2014.

27 Brzezińska K., Siedlecka M.: Truss-purlin Covering Fitted for Obtaining Solar Energy, Conference materials TRANSCOM 2013, 10th European Conference of Young Researchers and Scientists, Section 7: Civil Engineering, Žilina 24-26 June 2013, pp. 19-22.

28 Otwinowska K., Piotrowski R.: Comparison of roof rigidity for selected energy-efficient structures, Conference materials TRANSCOM 2013, 10th European Conference of Young Researchers and Scientists, Section 7: Civil Engineering, Žilina 24-26 czerwca 2013, pp. 225-228.

29 Kowal Z., Piotrowski R., Siedlecka M.: Comparative analysis of the reliability of energy-active covers of hall segments, Conference materials II Międzynarodowa Polsko-Ukraińska Konferencja Naukowo-Techniczna Aktualne Problemy Konstrukcji Metalowych, Gdańsk 27-28.11.2014, pp. 123-126.

30 Kowal Z.: The formation of space bar structures supported by the system reliability theory, Archives of Civil and Mechanical Engineering Vol. XI, No. 1, 2011, pp. 115 - 133.

31 Kowal Z.: Hazards associated with the load-bearing capacity of bar space structures during assembly and performance, Promysłowe Budiwnictwo Ta Inżenerni Sporudy 3/2011, pp. 34-40.

32 Kowal Z.: Probabilistic optimisation of the bearing capacity of conventional hall coverings, Structure and Enviroment, 2011, 3, pp. 10-19.

33 Kowal Z:: On Adjusting the Load Bearing Capacity of Decisive Members to Reliability Classes of Statically Determinate Complex Structures, Archives of Civil Engineering, Volume LIX, Issue 1, pp. 131-142.

34 Kowal Z: Instruments of probabilistic optimization of load bearing capacity and reliability of statically indeterminate complex structures, Archives of Civil Engineering, Volume LX, Issue 1, 2014, pp. 77-90.

35 Kowal Z., Szychowski A.: Patent No. PL 215515 B1. Construction of nodes of trusses from closed square or rectangular sections (in Polish), decision of 25-06-2013.

36 Kowal Z., Szychowski A.: Patent No. PL 219778 B1. Device for extraction and storage of thermal energy (in Polish), decision of. 12-11-2014.

37 Chwieduk D.: Solar energy in a building (in Polish), Arkady, Warszawa 2011.

38 Wołoszyn M. A.: Solar energy use in single-family houses (in Polish), Centralny Ośrodek Informacji Budownictwa, Warszawa 1991.

39 PN-EN 1990: 2004 Eurocode. Basis of structural design.

40 Kowal Z., Polak M., Szpila E., Wydra PP.: Spatial cover system "Zachód” (in Polish), Inżynieria i Budownictwo, 11/1976, pp. 421-424.

41 Kowal Z., Polak M., Szpila E., Wydra PP.: Spatial bar covers of industrial buildings with spans of 18, 24, 30, 36m in accordance with the "Zachód" system (in Polish), Inżynieria i Budownictwo, 3/1977, pp. 82-82.

42 PN-EN 1993-1-1:2006 Eurocode 3. Design of steel structures. Part 1-1. General rules and rules for buildings. 


\section{LIST OF FIGURES AND TABLES:}

Fig. 1. Concept of the structure for extraction, transportation and storage of solar radiation TE [20]

Rys. 1. Koncepcja konstrukcji do pozyskiwania, transportu i magazynowania energii cieplnej z promieniowania słonecznego [20]

Fig. 2. Energy-active segment of the structure with a tie: a) section, b) expansion segment division into assemblies [25]

Rys. 2. Energoaktywny segment struktury ze ściągiem: a) przekrój, b) podział segmentu dylatacyjnego na segmenty montażowe [25]

Fig. 3. Energy-active basket structure: a) section, b) expansion segment division into assemblies [23]

Rys. 3. Energoaktywna struktura koszowa: a) przekrój, b) podział segmentu dylatacyjnego na segmenty montażowe [23]

Fig. 4. Examples of the arrangement of energy-active (SE) segments of the building [23] - hatched areas Rys. 4. Przykłady rozmieszczenia energoaktywnych (SE) segmentów hali [23] - obszar zakreskowany 


\section{KSZTALTOWANIE ENERGOAKTYWNYCH SEGMENTÓW HAL}

Keywords: przekrycie energoaktywne, hala energoaktywna, probabilistyczna optymalizacja, segment dylatacyjny, segment energoaktywny, EC - energia cieplna, EE - energia elektryczna

W pracy zamieszczono podsumowanie stanu wiedzy na temat koncepcji konstrukcji energoaktywnych segmentów hal, przystosowanych do pozyskiwania energii elektrycznej (EE) i energii cieplnej (EC) z promieniowania słonecznego oraz transportu i magazynowania EC. Pokazano generalną koncepcję konstrukcji energoaktywnych segmentów hal oddylatowanych od segmentów konwencjonalnych w sposób umożliwiający rozmieszczenie i wymianę wyposażenia. Pokazano przykładowe koncepcje konstrukcji segmentów energoaktywnych, zoptymalizowane wg minimaksowej zasady: minimum termicznego wytężenia, maksimum nośności i niezawodności konstrukcji [34].

Optymalizację przeprowadzono poprzez rozdzielenie globalnych kinematycznie dopuszczalnych mechanizmów zniszczenia (KDMZ) przekryć hal i KDMZ słupów oraz zachowanie w oddylatowanych segmentach energoaktywnych minimum 4 równoległych sprzężeń zasadniczych elementów konstrukcji wg [34]. W przypadku równoległego sprzężenia minimum $\mathrm{n}=4$ głównych elementów sprawczych występuje trend zwiększenia nośności ponad normową [39] nośność obliczeniową wg wzoru [34] (3.1):

$$
s=\frac{\left(1-\frac{t_{2} v_{1}}{\sqrt{n}}\right)}{1-t_{2} v_{1}}
$$

gdzie:

t ${ }_{2}$ - wskaźnik niezawodności wg [39]; $v_{1}$ - współczynnik zmienności nośności sprzęganych elementów;

$\mathrm{n}$ - liczba ,jednakowych” elementów sprzężonych.

Pracę zilustrowano koncepcjami energoaktywnych segmentów konstrukcji hal przekrytych:

1. strukturą regularną,

2. strukturą zredukowaną,

3. regularną strukturą koszową,

4. strukturą zredukowaną ze ściągiem o spadkach umożliwiających samoczynne zsuwanie się śniegu z połaci dachowych w celu zwiększenia pozyskiwanej EC i EE.

Generalną zaletą stosowania struktur prętowych, obliczanych na podstawie norm przedmiotowych [42], w energoaktywnych segmentach konstrukcji hal o dostatecznej liczbie oczek liczonych wzdłuż hali jest to, że nośność i niezawodność wydzielonych segmentów hali jest większa od zalecanej w normie [39]. Dotyczy to segmentów szerokości minimum 4 oczek w przypadku struktur regularnych, natomiast w przypadku struktur zredukowanych szerokości minimum 7 oczek.

Zasadniczym zadaniem w pracy jest optymalne przystosowanie energoaktywnych segmentów konstrukcji wielkopowierzchniowych hal do pozyskiwania, transportu i magazynowania energii pozyskiwanej z promieniowania słonecznego. 